Article

\title{
The Roles of Formal and Informal Institutions in Small Tourism Business Development in Rural Areas of South China
}

\author{
Shuwen Liu ${ }^{1}$, Irene Cheng ${ }^{2}$ and Lewis Cheung ${ }^{3, *}$ \\ 1 Faculty of International Tourism and Management, City University of Macau, 4/F, Choi Kai Yau Building, \\ Avenida Padre Tomás Pereira Taipa, Macau, China; karen.sw.liu@gmail.com \\ 2 Department of Science and Environmental Studies, The Education University of Hong Kong, Tai Po, \\ New Territories, Hong Kong, China; nycheng@eduhk.hk \\ 3 Department of Social Science, The Education University of Hong Kong, Tai Po, New Territories, \\ Hong Kong, China \\ * Correspondence: ltocheung@eduhk.hk; Tel.: +852-2948-8908; Fax: +852-2948-8018
}

Received: 5 June 2017; Accepted: 3 July 2017; Published: 6 July 2017

\begin{abstract}
Taking a livelihood perspective to study tourism has become popular in recent years, but as an essential part of livelihood analysis, institutional processes have not yet received enough attention. This study focuses on the influences of formal and informal institutions on small tourism businesses in rural areas. A case study was conducted in Hong Kong, and the entitlements framework was adopted as an analytical tool. Based on qualitative data generated from field study, this paper describes how different groups of residents rely on institutions at multiple levels to gain assets and make legitimate effective use of them through operating small tourism businesses. Results indicate that the interaction between formal and informal institutions is mediated by a variety of organisations, particularly implementation authorities at the frontline, and determines residents' access to assets and the tourism market and subsequently, affects their start-up and operation of small tourism businesses. Informal institutions play a vital role in creating a favourable situation for local residents. However, this role may not satisfy small business owners who are non-local residents.
\end{abstract}

Keywords: small tourism business; institutions; access to assets; endowments and entitlements; livelihood

\section{Introduction}

Tourism has frequently been used throughout history as an engine to facilitate economic development in rural areas. Both local and non-local factors are responsible for shaping tourism development [1]. An essential criterion of the success of tourism destinations in rural areas is local residents' support. Residents' support, such as proactively participating in providing tourism services and reducing obstacles to planning proposals, can smooth the tourism development process. The perceived benefits of tourism development can be an essential driving force to gain local residents' support. In many rural tourism destinations, local residents are accustomed to providing some very simple and generic tourism services. Operating these small tourism businesses could allow them to share some economic benefits of the development.

Small tourism business plays a crucial role in providing tourism services to facilitate tourism development in rural areas. Such small-scale tourism services can provide opportunities for local people to generate economic benefits to sustain their livelihoods in tourism destinations [2-5]. Studying tourism from a livelihood perspective, including studying small tourism businesses, has become popular in recent years [6-8]. However, scholars seldom shed light on the influences of institutions on small tourism businesses, even though institutional processes are an essential component of livelihood 
analysis. Understanding the interaction of formal and informal institutions and the influences on small tourism business is important because institutions, whether through official rules or informal norms, influence people's behaviour in a given community by creating incentives for certain behaviours and disincentives for others [9]. Institutions can be a critical factor in determining whether, and in what form, residents may participate in tourism as small business operators. This paper relies on the entitlements framework as an analytical tool to interpret how formal and informal institutions function together to influence people's access to assets and their start-up and operation of small tourism business. Using empirical studies to explore the interaction of formal and informal institutions at multiple levels, this study helps to fill the research gap and provides guidance for policy makers to generate more pertinent policies and regulations for promoting sustainable tourism development, particularly in rural areas.

\section{Literature Review}

\subsection{Institutions and Sustainable Livelihoods}

While sustainable development has received widespread acclaim, it has also faced difficulties in being implemented [10]. The sustainable livelihoods framework and approach has been advocated by a number of scholars as a more practical way to address sustainability [11-14]. The sustainable livelihoods framework (Figure 1) is a useful tool for analysing people's livelihoods and has been widely used in various fields, particularly development studies. The framework assumes that people draw on a range of assets to carry out different strategies to achieve various livelihood outcomes [15]. Assets are the building blocks for livelihoods, and they are categorised into five types: natural, physical, financial, human and social capital $[16,17]$.

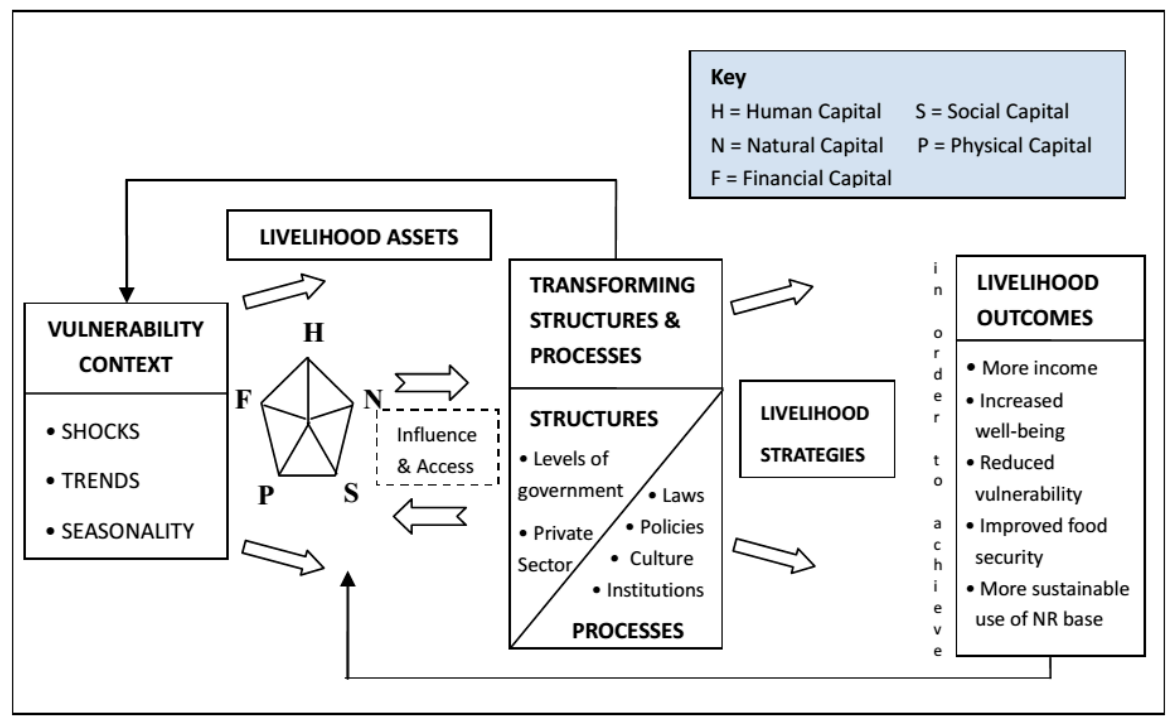

Figure 1. Sustainable livelihoods framework [16].

Many studies have noted that institutions and organisations play crucial roles in people's livelihoods because they determine people's access to assets [11,16,18-22]. Institutions are regarded as 'the rules of the game in society', whereas organisations are 'referees or players of the game' [23,24]. A variety of formal and informal institutions mediate the access to assets $[19,20,25,26]$. Formal institutions are rules under formal structures and are implemented by official entities, such as laws, regulations and market transactions, whereas informal institutions are self-enforcing rules that are carried out through the obligation mechanism, such as social norms and conventions $[19,20,27]$. Formal and informal institutions may exist at multiple levels (see Table 1), and there are different types of organisations in public and private sectors [16]. 
Table 1. Examples of formal and informal institutions at different levels [24].

\begin{tabular}{|c|c|c|}
\hline & Formal Institutions & Informal Institutions \\
\hline $\begin{array}{l}\text { International } \\
\text { Level }\end{array}$ & $\begin{array}{l}\text { International Trade Rules that } \\
\text { impose trade barriers or allow } \\
\text { dumping of subsidised products }\end{array}$ & $\begin{array}{l}\text { Political affinities which influence levels of } \\
\text { co-operation; Historical links between countries } \\
\text { manifested in favourable trading relationships }\end{array}$ \\
\hline National Level & $\begin{array}{l}\text { Property rights; Labour laws } \\
\text { (Union rights, immigration rules); } \\
\text { Intellectual property rights }\end{array}$ & $\begin{array}{l}\text { Position and attitudes towards women; } \\
\text { Patron-Client relationships }\end{array}$ \\
\hline Local Level & $\begin{array}{l}\text { Movement restrictions on } \\
\text { agricultural produce }\end{array}$ & Rules for share-rearing or share-cropping \\
\hline
\end{tabular}

Under the joint efforts of formal and informal institutions, people may gain better access to assets and generate more desirable livelihood outcomes. Getz's [25] study in El Pozo, Mexico demonstrated how formal and informal institutions functioned together to help farmers gain easier access to the market to sell agricultural products and earn more cash. However, formal and informal institutions may not always be supplementary to one another; conflicts may exist in some cases. The local authorities of Dak Lak in Vietnam initiated a formal institution to devolve forestland to indigenous households, but the indigenous people objected to the devolution imposed by the state and insisted on following customary practice [28]. The conflict was solved through a concession made by the state to allow the indigenous people to extract trees and cultivate fields for subsistence uses, while the transport and trade of timber remained tightly controlled by authorities [28]. In some other cases, the conflicts between formal and informal institutions were not solved, and the implementation of formal institutions failed to achieve its goal [29].

Although the importance of formal and informal institutions is well recognised, empirical studies have seldom been conducted to thoroughly understand how different institutions and organisations function at multiple levels to influence access to assets and livelihood outcomes. Different versions of the sustainable livelihoods framework $[16,17,30]$, though widely used, oversimplify the processes of institutions as a construct (see Figures 1 and 2).

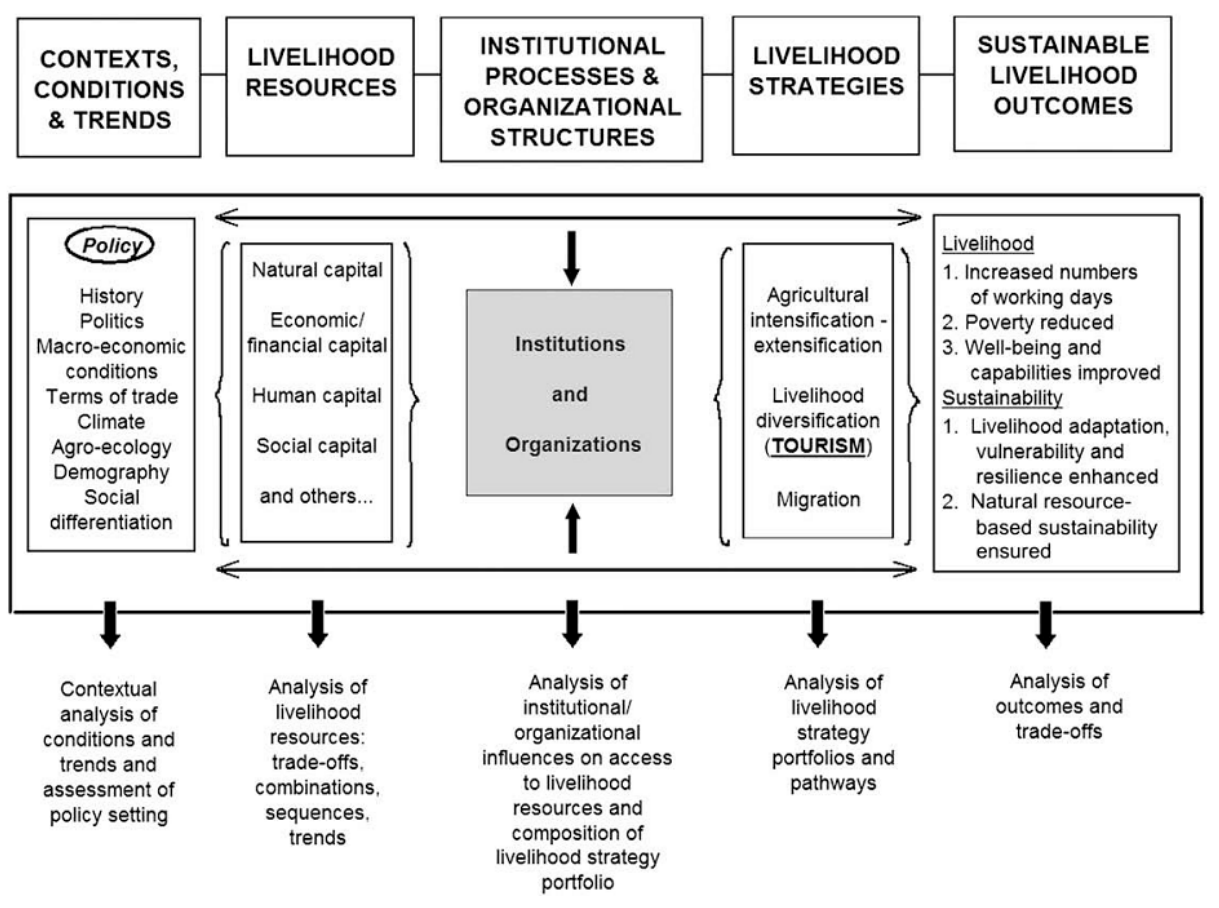

Figure 2. Sustainable livelihoods framework with tourism $[17,30]$. 


\subsection{Studies of Institutional Processes}

The roles played by institutions and organisations are complicated yet critical, because they determine how resources can be used for different livelihood strategies. The environmental entitlements framework (Figure 3) proposed by Leach, Mearns and Scoones [20] provides an analytical tool to illustrate how a set of interacting and overlapping institutions, both formal and informal, mediate people to gain access to and make use of natural resources to improve well-being. The framework helps to understand the ways in which different individuals and groups of a community gain capabilities, or a sense of well-being, by acquiring legitimate, effective command over resources through endowments and entitlements [20]. In their study, endowments is defined as "the rights and resources that social actors have", entitlements as "legitimate effective command over alternative commodity bundles", and capabilities as "what people can do or be with their entitlements" [20] (p. 233).

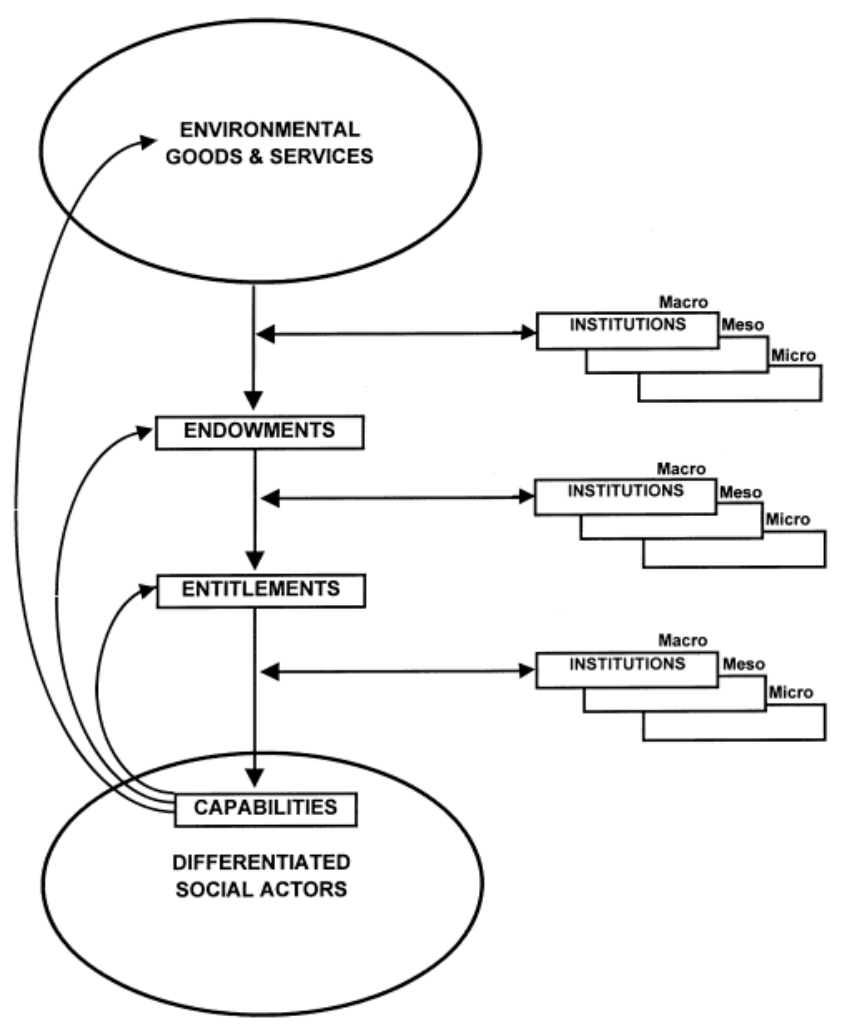

Figure 3. Environmental entitlements framework [20].

The environmental entitlements framework has been widely used by scholars in different fields [11,31-35], particularly in the field of natural resource management [28,36-39]. However, institutional analysis in tourism literature is very limited [40]. While studying tourism from a livelihood perspective has become more popular in recent years [41-46], institutional processes as an essential component of livelihood analysis have not really received enough attention. Several studies have addressed policies and regulations at the national level and their impacts on tourism development in certain communities, but the institutional processes through which policies and regulations are delivered remain unclear $[6,47,48]$. Several scholars have discussed the influences of institutional processes and organisational structures at the community level. For example, $\mathrm{Xu}$, et al. [49] analysed the heritage conservation planning and management of Hongcun Village in China, and Funnell and Bynoe [7] examined the outcomes of three different institutional arrangements for ecotourism governance. However, few studies shed light on the influences of institutional processes at different levels on small tourism businesses [50]. Given the importance of small tourism businesses as an engine 
of sustainable tourism, it is necessary to understand how formal and informal institutions interact collectively to affect the ways small tourism businesses operate in rural areas.

\section{Methods}

In order to interpret how institutions and organisations function together to influence people's access to assets and their participation in tourism as small tourism business operators, a case study of Tai $\mathrm{O}$ in Hong Kong is analysed using the entitlements framework (Figure 4).

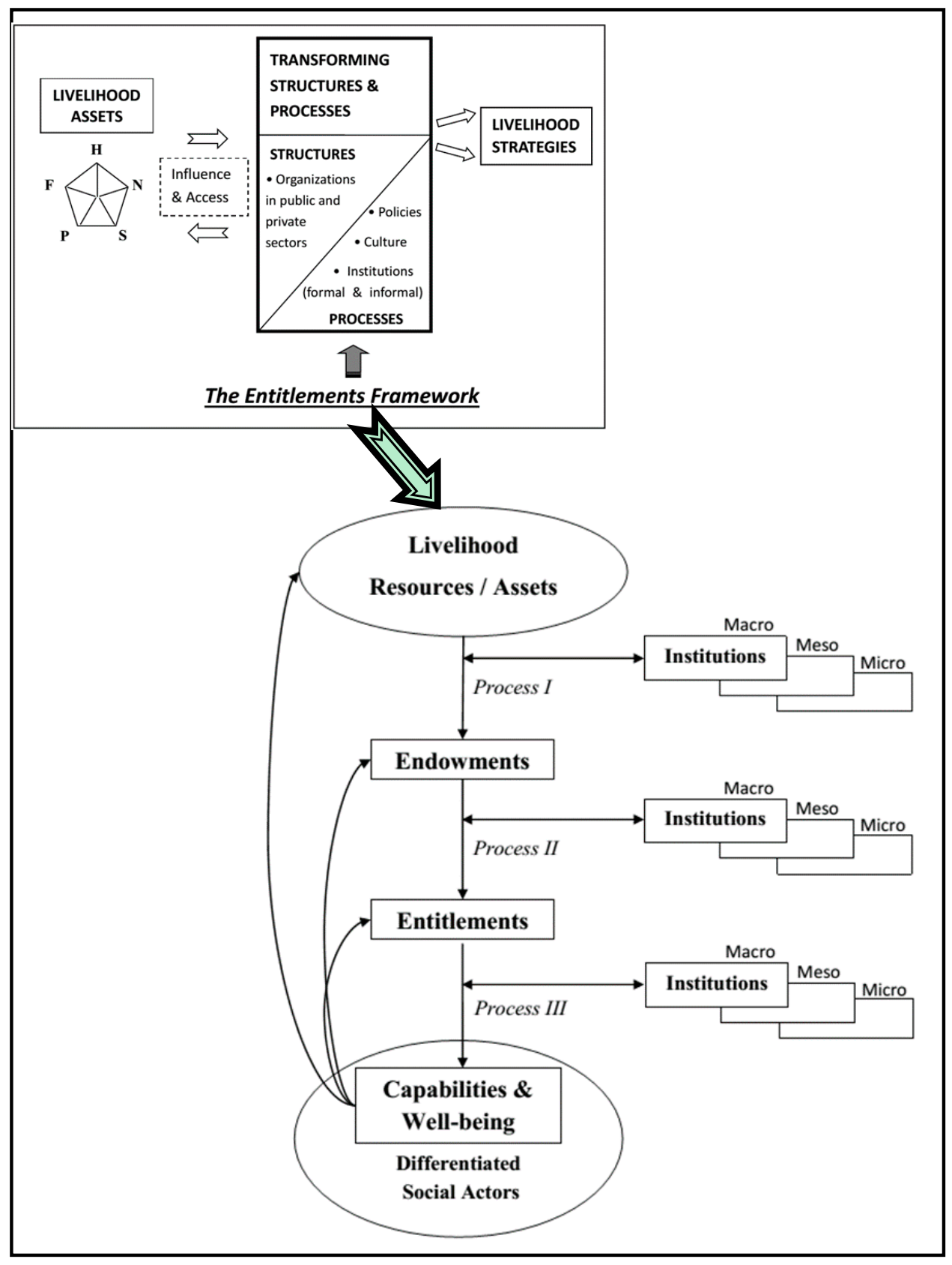

Figure 4. Entitlements framework as a supplementary analytical tool (Adapted from [16,20]).

Tai $\mathrm{O}$ is a traditional fishing community located at the western waters of Hong Kong near the Estuary of the Pearl River. As one of the oldest fishing villages in Hong Kong, Tai O is the only village to have retained the traditional form of fishery culture and unique buildings that were eventually promoted in rural tourism by the government [51]. The population of Tai $\mathrm{O}$ has experienced a serious 
decline from 4333 in 1986 to 2257 in 2011, and more than 30\% of the residents are aged above 65 years old [52]. To revitalise the community, in recent decades the Hong Kong Government has implemented an initiative to turn Tai $\mathrm{O}$ into a rural tourism destination in Hong Kong, through heavy promotion and marketing efforts. According to government projections, the number of tourists visiting Tai $\mathrm{O}$ could surge to 600,000 per annum, and an increasing number of visitors could have an enormous impact on the livelihoods of local residents [53]. An increasing number of small tourism-related businesses are being operated by both local and non-local residents, aiming to earn a living from the increasing number of visitors. Many properties have been turned into restaurants, stalls, and souvenir shops that are operated by both local and non-local residents of Tai $\mathrm{O}$.

Although Hong Kong has a high degree of autonomy as a special administrative region practicing in a capitalist system, both formal and informal institutions still play a strong role in tourism development. The analysis of the Tai $\mathrm{O}$ case provides a more thorough understanding of the influences of institutional processes on small tourism business operations in rural areas.

Qualitative research methods, including participant observation, unstructured and semi-structured interviews were adopted as the dominant methods for this study. Two field studies were administered in February and August 2015 to gain an in-depth understanding of the roles of institutions at multiple levels, and interviews were conducted with small tourism business operators, government officials at different administrative levels, members of rural committees, staff from different non-governmental organisation (NGOs), and representatives from the Chamber of Commerce (Table 2). The authors resided in the study area for two weeks during each field study period to observe the operation of small tourism business and interview stakeholders to gain first-hand data for this study. Unstructured interviews were conducted with a number of local residents to gain understanding of tourism as a livelihood option in the community. This was followed by semi-structured interviews with 22 selected interviewees (Table 2). There were 141 small tourism enterprises in Tai $\mathrm{O}$, which covered a wide range of business types, such as snack shops/stalls, dried seafood shops/stalls, restaurants, souvenir shops, boat tours, and B\&Bs [51]. Most of the interviewees in this study were small tourism business operators from different business types. The founders and senior management of local NGOs and the chairman of a local indigenous association were also interviewed to glean other stakeholders' views for this study. The preliminary data analysis was conducted after the first round of fieldwork, and new questions derived from the data were answered in the second round.

Table 2. List of interviewees of this study.

\begin{tabular}{ccc}
\hline Case & Interviewee No. & Description \\
\hline & T01 & Herbal tea stall operator \\
T02 & Snack shop operator \\
T03 & B\&B and café operator \\
T04 & Snack shop operator \\
T05 & Chairman of Tai O Rural Committee; Indigenous \\
& T06 & Founder of a local NGO \\
T07 & Snhabitant representative Tai Ond Rural Committee \\
T08 & Snack shop operator operator \\
T09 & Snack stall operator \\
T10 & Souvenir shop operator \\
T11 & Snack stall operator \\
& T12 & Souvenir shop operator \\
T13 & Seafood hawker \\
T14 & Snack hawker \\
T15 & Boat tour operator \\
T16 & Seafood hawker \\
T17 & T18 & Snack shop operator (outsider) \\
T19 & Dried seafood shop operator \\
T20 & Social worker of an NGO \\
T21 & Snack shop operator \\
T22 & Employee of a social enterprise \\
\hline
\end{tabular}




\section{Results}

Gaining access to property or public space (e.g., streets, pavements, or the plaza) to set up a stall is an important step in starting up a small tourism business. However, gaining access to property or public space may not be easy as it appears. In rural communities, different formal and informal institutions mediate people's access to this physical capital. Sometimes, an unfair distribution mechanism may lead to conflicts among people running small tourism businesses. From a livelihood perspective, the case study of Tai $\mathrm{O}$ in Hong Kong reveals that the possession of physical capital is as important for operating small tourism businesses, as the possession of financial, human and other types of capital. However, to achieve livelihood outcomes, it is more important to make effective use of the assets with which people have been endowed. These processes are also influenced by formal and informal institutions [51].

Based on the information obtained from the fieldwork in Tai O, Hong Kong, institutions at multiple levels that mediate the endowments, entitlements and improvement of capabilities and well-being are presented in Table 3.

Table 3. Endowments and entitlements in the case study of Tai O.

\begin{tabular}{|c|c|c|c|}
\hline \multicolumn{4}{|c|}{ Livelihood Assets: Property or Public Space (e.g., Streets or Pavement) as Physical Capital } \\
\hline \multirow{8}{*}{$\begin{array}{l}\text { Institutions } \\
\text { (Process I) }\end{array}$} & \multirow{4}{*}{ Macro-level } & Squatter clearance policy and relevant regulations & Formal \\
\hline & & Landlord and Tenant (Consolidation) Ordinance & Formal \\
\hline & & Buildings Ordinance & Formal \\
\hline & & Hawker Regulation and Summary Offences Ordinance & Formal \\
\hline & \multirow{4}{*}{ Micro-level } & $\begin{array}{l}\text { Property leasing mechanism between Tai O Rural } \\
\text { Committee and local residents }\end{array}$ & Formal \& informal \\
\hline & & $\begin{array}{l}\text { Property leasing between individuals in the form of } \\
\text { market transactions }\end{array}$ & Formal \\
\hline & & Conventions of using public space & Informal \\
\hline & & Customary property leasing and borrowing mechanisms & Informal \\
\hline \multicolumn{4}{|c|}{ Endowments (i.e., Gain Access to Assets) } \\
\hline \multirow{5}{*}{$\begin{array}{l}\text { Institutions } \\
\text { (Process II) }\end{array}$} & Macro-level & $\begin{array}{l}\text { Government's policy and fiscal instruments for } \\
\text { encouraging NGOs to provide social services }\end{array}$ & Formal \\
\hline & Meso-level & $\begin{array}{l}\text { Trading networks established and expanded by NGOs } \\
\text { and community organisations }\end{array}$ & Formal \\
\hline & \multirow{3}{*}{ Micro-level } & Convention of mutual support among kin and friends & Informal \\
\hline & & Intra-house bargaining arrangement for labour supply & Informal \\
\hline & & NGOs' workshop arrangement & Formal \& informal \\
\hline \multicolumn{4}{|c|}{ Entitlements (i.e., Effective Use of Assets to Obtain Utilities) } \\
\hline $\begin{array}{l}\text { Institution } \\
\text { (Process III) }\end{array}$ & Micro-level & Education as an expenditure priority & Informal \\
\hline \multicolumn{4}{|c|}{ Capabilities and Well-being (i.e., Livelihood Outcomes) } \\
\hline
\end{tabular}

\subsection{Endowments}

In Tai $\mathrm{O}$, people gain rights over property with the help of different institutions at the macro- and micro-levels (See Table 3, Institutions in Process I). For residents who use their own property to run a small tourism business, their access to property is affected by institutions at the macro-level, including the Buildings Ordinance [54], the squatter clearance policy and relevant regulations [55,56]. However, the conventional practice of building houses in the public space along the waterfront also influences residents' possession of property. It is common for Tai $\mathrm{O}$ residents living on the waterfront to build their houses above the water. This practice has been adopted for more than a hundred years, and the unique architecture, namely, stilt houses, has become a tourist attraction of Tai O [57]. While the land 
and public space occupied by residents belong to the government, the unauthorised building works are seldom penalised by the Building Department (Interviewee T01 \& T02, 10 February 2015). The conflicts between formal and informal institutions are solved by the authority's toleration. As a result, residents who would like to use their own property to run tourism businesses can expand their houses by building terraces to hold an outdoor snack shop or café (Interviewees T03 \& T04, 10 February 2015).

Regarding people (both residents and outsiders) who rent or borrow others' property to conduct tourism-related activities, their access is mediated not only by the policy and ordinances at the macro-level, but also by different property leasing mechanisms and customary property borrowing mechanisms as institutions at the micro-level. The property-leasing mechanism between Tai O Rural Committee and local residents could be considered as a mix of both formal and informal institutions. The rural committee managed the leasing of certain confiscated properties on behalf of the government, but this leasing did not completely follow market rules, as priority and preferential rights were given to local residents (Interviewee T05, 12 February 2015). Customary leasing and borrowing mechanisms were also popular in Tai O. As a key informant commented,

"Tai $O$ is a small and close-knit community. We don't have real estate agencies here, and the leasing business depends on the spread of leasing information through word of mouth in the community."

(Interviewee T06, 12 February 2015)

It is common for snack shop operators to rent shops through kinship and friendship networks at a preferential price, or even to use an idle property for free (Interviewees T07, T08 \& T09, 12 February 2015). Some snack hawkers have set up stalls in front of friends' or relatives' shops without paying a user fee (Interviewees T10 \& T11, 13 February 2015).

"This is the property of my Uncle that I do not need to pay rent as he was not living in Tai O anymore and allows me to use his property for small business."

(Interviewee T11, 13 February 2015)

For residents who use public space to run tourism-related businesses, their access to the public space is also influenced by institutions at the macro- and micro-levels. At the macro-level, the Hawker Regulation and Summary Offences Ordinance have been promulgated as formal institutions to regulate hawking activities [58,59]. However, these regulations have not been strictly followed in Tai $\mathrm{O}$ because they are contradictory to the institution at the micro-level: the conventional use of public space. Because of the prosperity of the salt and fishing industries, the market in Tai $\mathrm{O}$ was firmly established more than a century ago [60]. Hawking on the streets has been a conventional practice for a long time [61] and currently remains common. Although the government has announced the Hawking Regulation, there remain many unlicensed hawkers selling different kinds of things, such as vegetables, fish and goods, on the streets of Tai O. Because of the development of tourism, an increasing number of unlicensed hawkers have conducted tourism-related business in the past decade (Interviewee T12, 16 February 2015). Unlicensed hawkers mentioned that they were occasionally, but not often, caught by the Hawker Control Team (Interviewees T13, T14, T15 \& T16, 16 February 2015), because unlicensed hawkers have friends or relatives who tip them off, and help the hawkers to hide from the Hawker Control Team (Interviewees T14 \& T17, 16 February 2015), and also because of the relatively loose enforcement of hawker regulation in Tai O. Interviews with residents, outsiders and staff from different community organisations confirmed that enforcement of the Hawking Regulation in Tai O is looser than in urban areas (Interviewees T17, 16 February 2015; T18, T19 \& T20, 17 February 2015). The officers of the Food and Environmental Hygiene Department even tolerated shop owners and hawkers setting up stalls on the sidewalks in front of the shops to sell goods. As long as the hawkers gain shop owners' permission and remain on the sidewalks without blocking the roads, the Hawker Control Team rarely interferes with their peddling (Interviewees T01, 10 February 2015; T10, 12 February 2015 \& T21, 17 February 2015). 
"Government officers seldom patrol around. They do not usually stop illegal hawkers selling souvenirs in the public space even though they have patrolled. This definitely affects our business, as they can sell cheaper than me."

(Interviewee T10, 7 August 2015)

The remoteness of Tai $\mathrm{O}$ and this relatively loose enforcement allows the conventional use of public space to continue as an informal institution at the micro-level.

\subsection{Entitlements}

When people gain the rights to use property or public space, institutions at the macro-, meso- and micro-levels (see Table 3, Institutions in Process II) help them to make legitimate and effective use of this type of asset to conduct different livelihood activities. At the macro-level, the government's policy and fiscal instruments provide incentives for NGOs to play an active role in delivering social services. Under these formal institutions, NGOs in Tai O can mediate institutions at the meso-level to facilitate residents to gain income by using their endowments. For example, for some residents who would like to provide accommodation for tourists in their stilt houses, NGOs help them to establish and expand trading networks. NGOs play a similar role as travel agencies. On the one hand, they have recruited a few stilt house owners to form a supplier network. On the other hand, they use their connections with different social groups outside Tai $\mathrm{O}$ (e.g., schools and companies) to promote accommodation in the stilt houses as a type of experience activity (Interviewees T17, 16 February 2015; T20 \& T22, 17 February 2015).

“Our organisation provides help in lining up with stilt houses' owners to organise experiential tourism activities for visitors to allow outsiders to learn about the traditional living culture of the Tai O people."

(Interviewee T20, 17 February 2015)

Through NGOs' assistance, trading networks have been established between stilt house residents and tourist groups. Regarding people who operate other tourism businesses, tourism promotions initiated by the Tai O Rural Committee, NGOs and a membership organisation help to increase business opportunities and establish and expand trading networks. By using property and other types of capital, people can gain revenue through their participation as small tourism business operators.

People need to rely on different combinations of assets to operate small tourism businesses. Therefore, gaining access to property or public space is not enough; people also need to obtain other assets. Conventions of mutual support among kin and friends are informal institutions that function at the micro-level to help people gain access to human and financial capital. People may also need to rely on an intra-house bargaining arrangement for labour supply. For example, some elderly people may need to take care of their grandchildren, in addition to running their small tourism business. This group of participants needs to discuss labour arrangements with family members. NGOs' workshop arrangement also facilitates residents obtaining additional human capital (e.g., skills and knowledge) and social capital (e.g., social resources derived from expanded social networks) to participate in the tourism industry.

\subsection{Improvement of Capabilities and Well-Being}

After utilities are obtained through the effective use of assets, the use of revenue to contribute to social actors' capabilities and well-being may also be influenced by institutions. At the micro-level, families need to decide their expenditure priority for improving capabilities and well-being. In Chinese society, choosing education as an expenditure priority is a norm. In the Tai $\mathrm{O}$ case study, this also becomes an informal institution. Many of the respondents believe that by improving their children's 
education, the family's future capabilities and well-being would improve. Therefore, most parents in the community tend to seek better education opportunities for their children by sending them to schools in urban areas.

\section{Discussion and Conclusions}

While conflicts between formal and informal institutions are not uncommon in natural resource management projects in rural areas [25,28,29], the case study in Hong Kong suggests that institutional conflicts are also a common phenomenon when developing tourism in rural communities. The case study reveals that gaining access to property or public space as physical capital is crucial for local residents to participate in tourism-related activities. Access to this type of resource is mediated by both formal and informal institutions at multiple levels. When government regulations on buildings and hawkers as formal institutions contradict long-established conventions, implementation authorities at the frontline become essential to determine whether, and to what extent, local conventions as informal institutions can continue to function; this further influences the forms in which residents are allowed to take part in, and benefit from, tourism as small business operators and who may be in a more favourable position to start up a small tourism business.

In the case of Tai $\mathrm{O}$ in Hong Kong, because frontline officers made compromises in dealing with the conflicts by laxly implementing regulations, local residents who did not have enough start-up capital to open a shop were still able to participate in a less formal way, such as operating a stall or hawking on the street. Although local residents generally have less funding support and business skills than outsiders, their easy access to physical capital (i.e., property or public space) has paved the way for some of them to start up small tourism businesses. In Hong Kong, even in the rural community of Tai $\mathrm{O}$, access to property is difficult, as the costs of selling or renting property are expensive. Renting a property for business can erode a large portion of business revenue. The accessibility of property that could be converted into a small tourism business premises provides a great advantage for the local residents of Tai $\mathrm{O}$ to sustain their livelihoods through tourism. Such a favourable situation enhances local residents' competitiveness, even though they are less knowledgeable than outsiders in business operations.

In addition, allowing informal institutions to continue functioning in the community creates a favourable environment for local residents' benefit. Local residents who do not have premises for small tourism businesses can easily rent property from others in the community because they have tight relationships with individuals in the village and because premises owners would prefer to lease their properties to those with whom they are more familiar or share close relationships, such as relatives and friends. The Rural Committee could also play a vital role in allowing local residents to obtain access to property for the establishment of small tourism businesses. On the contrary, outsiders may face difficulties in setting up small tourism businesses in such rural communities, as gaining access to property for a business could be an issue for them to start up their businesses unless they are able to pay a higher rent. The role of informal institutions is therefore to balance the risks and opportunities of both local residents and outsiders in small tourism business development, which could ensure that local residents benefit from tourism development and avoid economic leakage from the local community. However, the hidden benefits of informal institutions for local residents may present another sensitive issue in relation to fairness in rural communities. This may trigger conflict between local and outside small business owners [28]. Outsiders may take further action to stop unfairness by promoting the stricter enforcement of formal institutions, for example, by complaining to organizations responsible for implementing formal institutions (e.g., law enforcement agencies) about addressing illegal hawkers and unlawful business operations by local residents.

The distribution of tourism benefits in a community has long been a concern in tourism studies $[3,62,63]$. Although tourism benefits are more likely to be kept in the destination through the promotion of small tourism businesses $[4,64]$, the disadvantaged group in a community may have difficulty taking part in tourism as small business operators. This study reveals that local residents rely 
more on informal institutions to gain access to assets when they cannot benefit from formal institutions. This indicates that the government departments, particularly the law enforcement agencies at the frontline, are more powerful. They can make discretionary decisions regarding whether, and to what extent, informal institutions are allowed to continue to function when there are conflicts between formal and informal institutions. Therefore, when small tourism business is encouraged as a tool to boost the local economy, the local government needs to pay attention to the existing and potential conflicts between formal and informal institutions that mediate residents' access to assets required for running small tourism businesses. These conflicts should be tackled cautiously; otherwise, they could lead to the further inequality of tourism benefits.

Through the empirical study, the authors have demonstrated the usefulness of the entitlements framework in understanding institutions' influences on small tourism business. However, this paper fails to address certain questions. The analysis shows that, during the operation of small tourism businesses, different organisations are involved in affecting business owners' access to the tourism market. This study focuses only on the role played by the authorities; further studies should explore the roles of other organisations and their relationships with institutions. Additionally, whether the findings of this empirical study are applicable to other regions is a question that also needs to be further explored.

Acknowledgments: The authors are grateful to the Start-Up Research Grant for providing funding support for this research project (Grant number HKIEd RG72/2014-2015R).

Author Contributions: Shuwen Liu carried out the field work, analysed the data and drafted the manuscript; Lewis Cheung analysed the field data and drafted the manuscript; and Irene Cheng drafted the manuscript.

Conflicts of Interest: The authors declare no conflict of interest.

\section{References}

1. Chang, T.C. Local uniqueness in the global village: Heritage tourism in Singapore. Prof. Geogr. 1999, 51, 91-103. [CrossRef]

2. Getz, D.; Carlsen, J.; Morrison, A. The Family Business in Tourism and Hospitality; Centre for Agriculture and Biosciences International: Wallingford, UK; Cambridge, MA, USA, 2004.

3. Simpson, M.C. Community benefit tourism initiatives-A conceptual oxymoron? Tour. Manag. 2008, 29, 1-18. [CrossRef]

4. Hallak, R.; Brown, G.; Lindsay, N.J. The place identity-Performance relationship among tourism entrepreneurs: A structural equation modelling analysis. Tour. Manag. 2012, 33, 143-154. [CrossRef]

5. Andriotis, K. Scale of hospitality firms and local economic development-Evidence from Crete. Tour. Manag. 2002, 23, 333-341. [CrossRef]

6. Ashley, C.; Jones, B. Joint ventures between communities and tourism investors: Experience in southern Africa. Int. J. Tour. Res. 2001, 3, 407. [CrossRef]

7. Funnell, D.C.; Bynoe, P.E. Ecotourism and institutional structures: The case of north Rupununi, Guyana. J. Ecotour. 2007, 6, 163-183. [CrossRef]

8. Mshenga, P.M.; Richardson, R.B. Micro and small enterprise participation in tourism in coastal Kenya. Small Bus. Econ. 2013, 41, 667-681. [CrossRef]

9. Holmes, R.M.; Miller, T.; Hitt, M.A.; Salmador, M.P. The interrelationships among informal institutions, formal institutions, and inward foreign direct investment. J. Manag. 2013, 39, 531-566. [CrossRef]

10. Wall, G. Sustainable development: Political rhetoric or analytical construct. Tour. Recreat. Res. 2002, 27, 89-91. [CrossRef]

11. Allison, E.H.; Horemans, B. Putting the principles of the sustainable livelihoods approach into fisheries development policy and practice. Mar. Policy 2006, 30, 757-766. [CrossRef]

12. Hopwood, B.; Mellor, M.; O’Brien, G. Sustainable development: Mapping different approaches. Sustain. Dev. 2005, 13, 38-52. [CrossRef]

13. Haque, C.E.; Deb, A.K.; Medeiros, D. Integrating conservation with livelihood improvement for sustainable development: The experiment of an oyster producers' cooperative in southeast Brazil. Soc. Nat. Resour. 2009, 22, 554-570. [CrossRef] 
14. Helmore, K.; Singh, N. Sustainable Livelihoods: Building on the Wealth of the Poor; Kumarian Press: Bloomfield, CO, USA, 2001.

15. Ashley, C.; Elliott, J.; Sikoyo, G.; Hanlon, K. Handbook for Assessing the Economic and Livelihood Impacts of Wildlife Enterprises. Available online: http://www.odi.org.uk/rpeg/finalmethodology.pdf (accessed on 3 February 2010).

16. Department for International Development. Sustainable Livelihoods Guidance Sheets: Section 2. Available online: http://www.eldis.org/vfile/upload/1/document/0901/section2.pdf (accessed on 4 November 2009).

17. Scoones, I. Sustainable Rural Livelihoods: A Framework for Analysis; Institute of Development Studies: Brighton, UK, 1998.

18. Haan, L.D.; Zoomers, A. Exploring the frontier of livelihoods research. Dev. Chang. 2005, 36, $27-47$. [CrossRef]

19. Johnson, C.A. Rules, Norms and the Pursuit of Sustainable Livelihoods; Institute of Development Studies: Brighton, UK, 1997.

20. Leach, M.; Mearns, R.; Scoones, I. Environmental entitlements: Dynamics and institutions in community-based natural resource management. World Dev. 1999, 27, 225-247. [CrossRef]

21. Morrison, J.; Dorwood, A.; Kydd, J. Sustainable Livelihoods and New Institutional Economics; Wye College: London, UK, 2000.

22. Watson, E.E. Examining the potential of indigenous institutions for development: A perspective from Borana, Ethiopia. Dev. Chang. 2003, 34, 287-310. [CrossRef]

23. North, D. Institutions, Institutional Change, and Economic Performance; Cambridge University Press: New York, NY, USA, 1990.

24. Department for International Development. Sustainable Livelihoods Guidance Sheets: Section 5. Available online: http:/ /www.eldis.org/vfile/upload/1/document/0901/section5.pdf (accessed on 25 July 2010).

25. Getz, C. Social capital, organic agriculture, and sustainable livelihood security: Rethinking agrarian change in Mexico. Rural Sociol. 2008, 73, 555-579. [CrossRef]

26. Warren, M.R.; Thompson, J.P.; Saegert, S. The role of social capital in combating poverty. In Social Capital and Poor Communities; Saegert, S., Thompson, J.P., Warren, M.R., Eds.; Russel Sage Foundation: New York, NY, USA, 2001; pp. 1-30.

27. Jutting, J. Informal Institutions: How Social Norms Help or Hinder Development; Development Centre of the Organisation for Economic Co-operation and Development: Pairs, France, 2007.

28. Sikor, T.; Nguyen, T.Q. Why may forest devolution not benefit the rural poor? Forest entitlements in Vietnam's central highlands. World Dev. 2007, 35, 2010-2025. [CrossRef]

29. McCusker, B.; Oberhauser, A.M. An assessment of women's access to natural resources through communal projects in South Africa. GeoJournal 2006, 66, 325-339. [CrossRef]

30. Tao, T.C.H.; Wall, G. Tourism as a sustainable livelihood strategy. Tour. Manag. 2009, 30, 90-98. [CrossRef]

31. Mbaiwa, J.E. Wildlife resource utilisation at moremi game reserve and khwai community area in the Okavango Delta, Botswana. J. Environ. Manag. 2005, 77, 144-156. [CrossRef] [PubMed]

32. Forsyth, T. Ecological functions and functionings: Towards a senian analysis of ecosystem services. Dev. Chang. 2015, 46, 225-246. [CrossRef]

33. Teye, J.K. Analysing forest resource governance in Africa: Proposition for an integrated policy network model. For. Policy Econ. 2013, 26, 63-70. [CrossRef]

34. Upton, C. Adaptive capacity and institutional evolution in contemporary pastoral societies. Appl. Geogr. 2012, 33, 135-141. [CrossRef]

35. Chareunsy, A.K. Social hierarchy and the inequalities of access: Evidence from rural southern Laos. J. Contemp. Asia 2012, 42, 276-297. [CrossRef]

36. Altman, J.; Cochrane, M. Sustainable development in the indigenous-owned savanna: Innovative institutional design for cooperative wildlife management. Wildl. Res. 2005, 32, 473-480. [CrossRef]

37. Altrichter, M. Assessing potential for community-based management of peccaries through common pool resource theory in the rural area of the argentine chaco. Ambio 2008, 37, 108-113. [CrossRef]

38. Ha, T.T.T.; van Dijk, H.; Bush, S.R. Mangrove conservation or shrimp farmer's livelihood? The devolution of forest management and benefit sharing in the Mekong Delta, Vietnam. Ocean Coast. Manag. 2012, 69, 185-193. [CrossRef] 
39. Kamoto, J.; Clarkson, G.; Dorward, P.; Shepherd, D. Doing more harm than good? Community based natural resource management and the neglect of local institutions in policy development. Land Use Policy 2013, 35, 293-301. [CrossRef]

40. Hughes, D.M. Rezoned for business: How eco-tourism unlocked black farmland in eastern Zimbabwe. J. Agrar. Chang. 2001, 1, 575-599. [CrossRef]

41. Nyaupane, G.P.; Poudel, S. Linkages among biodiversity, livelihood, and tourism. Ann. Tour. Res. 2011, 38, 1344-1366. [CrossRef]

42. Simpson, M.C. An integrated approach to assess the impacts of tourism on community development and sustainable livelihoods. Community Dev. J. 2009, 44, 186-208. [CrossRef]

43. Wu, M.Y.; Pearce, P.L. Host tourism aspirations as a point of departure for the sustainable livelihoods approach. J. Sustain. Tour. 2014, 22, 440-460. [CrossRef]

44. Sebele, L.S. Community-based tourism ventures, benefits and challenges: Khama rhino sanctuary trust, central district, Botswana. Tour. Manag. 2010, 31, 136-146. [CrossRef]

45. Lapeyre, R. The grootberg lodge partnership in Namibia: Towards poverty alleviation and empowerment for long-term sustainability? Curr. Issues Tour. 2011, 14, 221-234. [CrossRef]

46. Nepal, S.K. Sustainable tourism, protected areas and livelihood needs of local communities in developing countries. Int. J. Sustain. Dev. World Ecol. 1997, 4, 123-135. [CrossRef]

47. Wang, G.; Innes, J.L.; Wu, S.W.; Krzyzanowski, J.; Yin, Y.; Dai, S.; Zhang, X.; Liu, S. National park development in China: Conservation or commercialization? Ambio 2012, 41, 247-261. [CrossRef] [PubMed]

48. Alipour, H.; Kilic, H. An institutional appraisal of tourism development and planning: The case of the Turkish Republic of North Cyprus (TRNC). Tour. Manag. 2005, 26, 79-94. [CrossRef]

49. Xu, H.; Wan, X.; Fan, X. Rethinking authenticity in the implementation of China's heritage conservation: The case of hongcun village. Tour. Geogr. 2014, 16, 799-811. [CrossRef]

50. Han, G.; Wu, P.; Huang, Y.; Yang, Z. Tourism development and the disempowerment of host residents: Types and formative mechanisms. Tour. Geogr. 2014, 16, 717-740. [CrossRef]

51. Liu, S.; Cheung, L.T.O. Sense of place and tourism business development. Tour. Geogr. 2016, 18, 174-193. [CrossRef]

52. Hong Kong Census and Statistics Department. 2011 Population Census—Fact Sheet for the Whole Territory of Hong Kong. Available online: http://www.census2011.gov.hk/en/district-profiles/dcd-hk.html (accessed on 28 January 2013).

53. Hong Kong Planning Department. Study on Revitalization of Tai O. Available online: http:/ /www.pland.gov. hk/pland_en/p_study/comp_s/tai_o/a-web-recommendation/3strategy.htm (accessed on 5 June 2015).

54. Hong Kong Department of Justice. Chapter 123 Buildings Ordinance. Available online: $\quad$ http:/ / www.legislation.gov.hk/blis_pdf.nsf/6799165D2FEE3FA94825755E0033E532/ 439979DE5B92D2C9482575EE003EBFB6/\$FILE/CAP_123_e_b5.pdf (accessed on 6 March 2013).

55. Legislative Council of Hong Kong. Clearance of Squatter Areas. Available online: http:/ /www.legco.gov. hk/yr99-00/english/panels/hg/cl_squat/papers/a587e.pdf (accessed on 22 March 2012).

56. Legislative Council of Hong Kong. Policy for the Clearance of Squatter Areas and Temporary Housing Areas. Available online: http:/ /www.legco.gov.hk/yr00-01/chinese/panels/hg/papers/a79c01.pdf (accessed on 22 March 2012).

57. Cheung, D. Restoration of Tai O stilt houses: Living improvement for squatter poor and conservation for heritage area. Hong Kong Inst. Archit. J. 2010, 59, 52-53.

58. Food and Environmental Hygiene Department. Control of Licensed and Unlicensed Hawkers. Available online: http://www.fehd.gov.hk/english/pleasant_environment/hawker/control.html (accessed on 5 February 2013).

59. Hong Kong Department of Justice. Chapter 132ai Hawker Regulation (Empowering Section). Available online: http:/ / www.legislation.gov.hk/blis_pdf.nsf/4F0DB701C6C25D4A4825755C00352E35/ 8D0301A6CAE5A6A1482575EE004058E1/\$FILE/CAP_132AI_e_b5.pdf (accessed on 13 February 2012).

60. Chan, L.W.T. The Economic Geography of Tai O, Lantao Island; University of Hong Kong: Hong Kong, China, 1968.

61. Wong, W.K. Tai O_Love Stories of the Fishing Village; Wong Wai King: Hong Kong, China, 2000.

62. Snyder, K.A.; Sulle, E.B. Tourism in maasai communities: A chance to improve livelihoods? J. Sustain. Tour. 2011, 19, 935-951. [CrossRef] 
63. Timothy, D.J. Participatory planning: A view of tourism in Indonesia. Ann. Tour. Res. 1999, 26, $371-391$. [CrossRef]

64. Timothy, D.J. Tourism and community development issues. In Tourism and Development: Concepts and Issues; Sharpley, R., Telfer, D.J., Eds.; Channel View Publications: Clevedon, UK, 2002; pp. 149-164.

(c) 2017 by the authors. Licensee MDPI, Basel, Switzerland. This article is an open access article distributed under the terms and conditions of the Creative Commons Attribution (CC BY) license (http:/ / creativecommons.org/licenses/by/4.0/). 